\title{
TINDAK TUTUR EKSPRESIF PADA BAK TRUK SEBAGAI ALTERNATIF MATERI AJAR PRAGMATIK
}

\author{
Evi Chamalah dan Turahmat \\ Program Studi Pendidikan Bahasa dan Sastra Indonesia \\ Universitas Islam Sultan Agung \\ chamalah@unissula.ac.id
}

\begin{abstract}
Expressive speech act is intended speech acts that speakers ujarannya interpreted as an evaluation of the things mentioned in the speech. Speech-speech praising, say thank you, criticize, complain, blame, congratulate, flattering, belongs to the kind of expressive speech acts. The speech can be expressed through verbal media and media writing. There is also a form of advertising as written on the means of transportation of which is on the truck.
\end{abstract}

Keywords: Acts of speech, tailgate, Teaching Materials

\section{ABSTRAK}

Tindak tutur ekspresif adalah tindak tutur yang dimaksudkan penuturnya agar ujarannya diartikan sebagai evaluasi tentang hal yang disebutkan di dalam tuturan itu. Tuturan-tuturan memuji, mengucapkan terima kasih, mengkritik, mengeluh, menyalahkan, mengucapkan selamat, menyanjung, termasuk ke dalam jenis tindak tutur ekspresif. Tuturan tersebut dapat diekspresikan melalui media lisan dan media tulis. Ada juga yang berupa iklan seperti yang tertulis pada alat-alat transportasi di antaranya adalah pada bak truk.

Kata Kunci: Tindak tutur, Bak truk, Materi Ajar

\section{PENDAHULUAN}

Tuturan dapat diekspresikan melalui

media lisan dan media tulis. Dalam media tulis, tuturan disampaikan oleh penutur kepada mitra tuturnya. Penutur dapat merealisasikan tuturan lisan maupun tulis dengan memanfaatkan media massa atau media cetak. Media massa yang dimanfaatkan untuk tuturan lisan adalah media massa elektronik seperti radio dan televisi. Sementara media cetak seperti surat kabar, novel, cerpen, majalah, dan tabloid. Ada juga yang berupa iklan-iklan seperti baliho, iklan selebaran ataupun di tempat umum seperti pada alat transportasi seperti bus, kereta api, bahkan pada bak truk.

Efektif tidaknya penggunaan bahasa bergantung pada pemahaman terhadap makna-makna yang tersirat dalam tuturan. Dari sebuah tuturan, maksud dan tujuannya 
tidak selalu sama dengan apa yang diharapkan tetapi justru sering berbeda dengan apa yang sebenarnya dituturkan. Dengan kata lain, bahwa dalam bertutur atau berkomunikasi dalam menyampaikan maksud tidak selalu disampaikan secara langsung. Pada dasarnya tindak tutur yang dihasilkan bergantung pada tujuan atau arah tuturan untuk mencapai tujuan, tindak tutur harus disesuaikan dengan situasi tuturan. Situasi tuturan tersebut merupakan situasi sosial yang aktual karena terjadi dalam lingkungan masyarakat yang luas dan berbeda. Jadi situasi tutur dapat mempengaruhi tercapai tujuan tuturan. Tindak tutur ekspresif adalah tindak tutur yang dimaksudkan penuturnya agar ujarannya diartikan sebagai evaluasi tentang hal yang disebutkan di dalam tuturan itu (Rustono 1999:39). Fraser (dalam Rustono 1999:39) menyebutkan tindak tutur ekspresif dengan istilah evaluatif. Tindak tutur ekspresif adalah tindak tutur yang dimaksudkan penuturnya agar ujarannya diartikan sebagai evaluasi tentang hal yang disebutkan di dalam tuturan itu. Tuturantuturan memuji, mengucapkan terima kasih, mengkritik, mengeluh, menyalahkan, mengucapkan selamat, menyanjung, termasuk ke dalam jenis tindak tutur ekspresif ini (Rustono 1999:41).

Kajian pragmatik dalam tindak tutur ekspresif yang tertulis pada bak truk merupakan kajian dari sudut pandang pragmatik. Pada kajian pragmatik ini akan membahas tentang tindak tutur ekspresif yang tertulis pada bak truk sebagai alternatif materi ajar Pragmatik.

Penelitian ini bertujuan sebagai berikut. (1) Mendeskripsikan jenis-jenis tindak tutur ekspresif yang tertulis pada bak truk. (2) Mendeskripsikan alternatif bentuk materi ajar Pragmatik melalui tindak tutur ekspresif yang tertulis pada bak truk. Penelitian ini diharapkan dapat bermanfaat baik secara teoretis maupun praktis. Manfaat teoretis, (1) menambah khasanah ilmu Pragmatik, (2) menambah pengetahuan 
bagaimana cara menerapkan tindak tutur ekspresif yang tertulis pada bak truk sebagai alternatif materi ajar Pragmatik. Manfaat praktis, (1) sebagai salah satu acuan untuk melakukan penelitian kajian tindak tutur ekspresif, (2) sebagai alternatif materi ajar Pragmatik.

\section{Landasan Teoretis}

\section{Tindak Tutur}

Tindak tutur merupakan hal penting di dalam kajian Pragmatik. Tindak tutur digunakan karena pada dasarnya seseorang dalam mengucapkan tidak semata-mata mengatakan sesuatu dengan pengucapan dengan kalimat itu. Di dalam pengucapan kalimat itu ia juga menindakkan sesuatu (Purwo 1990:19). Sejalan dengan pendapat tersebut Gunawan (dalam Rustono 1999:32) menyatakan bahwa mengujarkan sebuah tuturan dapat dilihat sebagai melakukan tindakan, disamping memang mengucapkan atau mengujarkan tuturan itu.

Kegiatan melakukan tindakan itulah yang merupakan tindak ujar atau tindak tutur.
Leech (dalam Rustono 1999:33) berpendapat bahwa sebuah tindak tutur hendaknya mempertimbangkan lima aspek situasi tutur yang mencakupi: (1) penutur dan mitra tutur, (2) konteks tuturan, (3) tujuan tuturan, (4) tindak tutur sebagai bentuk tindakan atau aktivitas, dan (5) tuturan sebagai produk tindak verbal. Atas dasar sejumlah kriteria, ada beberapa jenis tindak tutur, yaitu tindak tutur konstatif, performatif, lokusi, ilokusi, perlokusi, representatif, direktif, ekspresif atau evaluatif, komisif, deklarasi atau astablisif atau isbati, langsung, tidak langsung, langsung harfiah, langsung tidak harfiah, tidak langsung harfiah, dan tidak langsung tidak harfiah (Rustono 1999:32).

Berdasarkan penjelasan di atas, maka tindak tutur dalam suatu kalimat merupakan penentu makna kalimat itu, makna suatu kalimat tidak ditentukan oleh satu-satunya tindak tutur seperti yang berlaku dalam kalimat yang sedang diujarkan, tetapi selalu dalam prinsip adanya kemungkinan untuk 
menyatakan secara tepat apa yang dimaksud oleh penuturnya.

\section{Jenis Tindak Tutur}

Jenis tindak tutur menurut para ahli bahasa ada tiga jenis, yaitu lokusi, ilokusi, dan perlokusi. Lokusi adalah tindak tutur yang dimaksudkan untuk menyatakan sesuatu. Lokusi semata-mata merupakan tindak tutur yang tidak mengucapkan sesuatu dengan kata dan makna kalimat sesuai dengan makna kata itu di dalam kamus dan makna itu menurut kaidah sintaksis (Gunarwan dalam Rustono 1999:37). Menurut Rahardi (2007:71), tindak lokusioner adalah tindak tutur dengan kata, frasa, dan kalimat sesuai dengan makna yang dikandung oleh kata, frasa, dan kalimat. Dalam tindak lokusioner tidak dipermasalahkan maksud dan fungsi tuturan yang disampaikan oleh si penutur. Contoh tuturan yang berbunyi "tanganku gatal", semata-mata hanya dimaksudkan untuk memberitahu pihak si mitra tutur bahwa pada saat dimunculkannya tuturan tersebut tangan si penutur sedang dalam keadaan sakit gatal. Jenis tindak tutur yang kedua adalah tindak tutur ilokusi. Tindak tutur ilokusi adalah tindak melakukan sesuatu (Wijana 1996:18). Berbeda dari lokusi, tindak ilokusi merupakan tindak tutur yang mengandung maksud dan fungsi atau daya tuturan. Tindak ilokusi tidak mudah diidentifikasi berkaitan dengan siapa bertutur kepada siapa, kapan, dan di mana tindak tutur itu dilakukan, dsb. Contoh tuturan "tanganku gatal" yang diucapkan oleh penutur, bukan semata-mata dimaksudkan untuk memberitahu kepada sang mitra tutur bahwa pada saat dituturkannya tuturan tersebut rasa gatal sedang menyerang dan bersarang pada lengan tangan si penutur. Namun lebih dari semua itu, bahwa penutur melakukan tindakan tertentu yang berkaitan dengan rasa gatal pada tangan atau lengannya itu. Misalkan, mengambilkan obat penghilang rasa gatal, dsb. 
Jenis tindak tutur yang yang ketiga adalah tindak tutur perlokusi. Tindak tutur perlokusi adalah tindak tutur yang pengutaraannya dimaksudkan untuk mempengaruhi lawan tutur (Wijana 1996:1920). Contoh tuturan "Tanganku gatal", dapat digunakan untuk menumbuhkan efek rasa takut kepada si mitra tutur. Rasa takut itu muncul, misalkan karena orang yang sedang menuturkan tuturan itu berprofesi sebagai tukang pukul yang pada keseharian hidupnya sangat erat dengan kegiatan memukul dan melukai orang lain yang menjadi lawan atau mangsanya.

Jenis tindak tutur yang lain ada lima jenis yaitu tindak tutur representatif, direktif, ekspresif, komisif, dan deklarasi (Searle dalam Rustono 1999:39). Tindak tutur yang pertama yaitu tindak tutur representatif, yaitu tindak tutur yang mengikat penuturnya akan kebenaran atas apa yang diujarkan. Termasuk dalam jenis tindak tutur ini adalah tuturantuturan menyatakan, menuntut, mengakui, melaporkan, menunjukkan, menyebutkan, memberikan kesaksian, berspekulasi, dsb (Rustono 1999:40). Contoh tuturan "Sebentar lagi dia keluar”.

Jenis tindak tutur yang kedua adalah tindak tutur direktif. Tindak tutur direktif adalah tindak tutur yang dimaksudkan penuturnya agar mitra tutur melakukan tindakan yang disebutkan di dalam tuturan itu. Termasuk dalam jenis tindak tutur ini adalah tuturan memaksa, mengajak, meminta, menyuruh, menagih, mendesak, memohon, menyarankan, memerintah, memberikan aba-aba, menantang. Contoh tuturan "Ambilkan sepatuku!"

Jenis tindak tutur yang ketiga adalah tindak tutur ekspresif atau evaluatif. Tindak tutur ekspresif adalah tindak tutur yang dimaksudkan penuturnya agar ujarannya diartikan sebagai evaluasi tentang hal yang disebutkan di dalam tuturan itu. Tuturantuturan memuji, mengucapkan terima kasih, mengkritik, mengeluh, menyalahkan, mengucapkan selamat, menyanjung, termasuk ke dalam jenis tindak tutur 
ekspresif. Contoh tuturan "Tindakanmu luar biasa".

Jenis tindak tutur yang keempat adalah tindak tutur komisif. Tindak tutur komisif adalah tindak tutur yang mengikat penuturnya untuk melaksanakan apa yang disebutkan di dalam tuturannya. Berjanji, bersumpah, mengancam, menyatakan kesanggupan, berkaul, merupakan tuturan yang termasuk ke dalam jenis tindak tutur komisif (Rustono 1999:42).

Jenis tindak tutur yang kelima adalah tindak tutur deklarasi. Tindak tutur deklarasi adalah tindak tutur yang dimaksudkan penuturnya untuk menciptakan hal (status, keadaan, dan sebagainya) yang baru. Tindak tutur ini disebut juga tindak tutur isbati. Tuturan-tuturan dengan maksud mengesahkan, memutuskan, membatalkan, melarang, mengizinkan, mengabulkan, mengangkat, menggolongkan, mengampuni, memaafkan, termasuk ke dalam tindak tutur deklarasi. Contoh tuturan "Jangan mengambil makanan itu!”.

\section{Tindak Tutur Ekspresif}

Tindak tutur ekspresif adalah tindak tutur yang dimaksudkan penuturnya agar ujarannya diartikan sebagai evaluasi tentang hal yang disebutkan di dalam tuturan itu (Rustono 1999:39). Tindak tutur ekspresif disebut juga tindak tutur evaluatif. Tuturantuturan memuji, mengucapkan terima kasih, mengkritik, mengeluh, menyalahkan, mengucapkan selamat, menyanjung, termasuk ke dalam jenis tindak tutur ekspresif. Jenis-jenis tindak tutur ekspresif yaitu (a) tindak tutur ekspresif dengan indikator mengkritik, (b) tindak tutur ekspresif dengan indikator mengeluh, (c) tindak tutur ekspresif dengan indikator menyalahkan, (d) tindak tutur ekspresif dengan indikator memuji, (e) tindak tutur ekspresif dengan indikator mengucapkan terima kasih, (f) tindak tutur ekspresif dengan indikator mengucapkan selamat, (g) tindak tutur ekspresif dengan indikator menyanjung.

\section{Alternatif Materi Ajar Pragmatik}


Alternatif adalah pilihan di amtara dua atau beberapa kemungkinan (Depdiknas 2005:33). Selanjutnya, materi ajar/materi pembelajaran adalah merupakan seperangkat informasi yang diserap peserta didik melalui proses pembelajaran. Secara umum, sifat materi pembelajaran meliputi fakta, konsep, prinsip dan keterampilan. Fakta pada materi artinya materi yang disajikan dalam pembelajaran berdasarkan kaidah-kaidah materi yang sesuai dengan teori pada panduan. Konsep dan prinsip yang dimaksud dalam materi adalah dengan berpegang pada materi yang telah dipelajari untuk menganalisis tindak tutur ekspresif (Iskandarwassid dan Sunendar 2009:171).

Materi ajar dalam mata kuliah Pragmatik meliputi fakta, konsep, prinsip dan keterampilan. Salah satu capaian pembelajaran dalam mata kuliah tersebut adalah adalah mahasiswa memiliki kemampuan dalam menentukan jenis tindak tutur.

\section{METODE PENELITIAN}

Dalam bagian ini akan diuraikan mengenai pendekatan penelitian, data dan sumber data, teknik pengumpulan data, metode dan teknik analisis data, teknik pemaparan analisis data.

\section{Pendekatan Penelitian}

Pendekatan dalam penelitian ini adalah pendekatan deskriptif kualitatif. Pendekatan deskriptif adalah prosedur penelitian yang menghasilkan data deskripsi berupa kata-kata tertulis atau lisan dari orang-orang dan perilaku yang diamati (Moleong 2002:3). Pendekatan deskriptif adalah pendekatan yang diperoleh berupa kata-kata, gambar, dan bukan angka-angka. Sehingga hasil penelitian akan berupa kutipan-kutipan data untuk memberi gambaran penyajian (Moleong 2002:6).

\section{Data dan Sumber Data}

Data dalam penelitian ini berupa tuturantuturan yang mengandung tindak tutur ekspresif, khususnya tuturan yang tertulis pada bak truk. Sumber tuturan adalah kata- 
kata yang tertulis pada bak truk yang melintasi wilayah Semarang pada periode Maret-April.

\section{Teknik Pengumpulan Data}

Tahap pengumpulan data dalam penelitian ini dengan menggunakan teknik catat. Teknik catat adalah teknik pengumpulan data yang dilakukan dengan pencatatan pada kartu data yang segera dilanjutkan dengan klasifikasi.

\section{Metode dan Teknik Analisis Data}

Metode yang digunakan dalam upaya menemukan kaidah dalam tahap analisis data ada dua yaitu metode padan dan metode agih. Metode padan adalah metode yang alat penentunya di luar, terlepas, dan tidak menjadi bagian dari bahasa yang bersangkutan, sedangkan metode agih adalah metode yang alat penentunya justru bagian dari bahasa yang bersangkutan itu sendiri (Sudaryanto 1993:13-15).

5. Teknik Pemaparan Hasil Analisis

\section{Data}

Data yang telah dianalisis menghasilkan kaidah yang harus ditulis untuk kemudian dimasyarakatkan. Cara yang dikenal sebagai teknik dalam analisis data yaitu bersifat formal dan informal. Secara formal adalah perumusan dengan tanda dan lambinglambang, sedangkan secara informal adalah perumusan dengan kata-kata (Sudaryanto 1993:144). Dalam penelitian ini hanya menggunakan teknik analisis informal.

\section{HASIL PENELITIAN DAN}

\section{PEMBAHASAN}

\section{Hasil Penelitian tentang Tindak Tutur} Ekspresif

Berdasarkan hasil penelitian dapat ditemukan tindak tutur ekspresif dengan indikator: (a) tindak tutur ekspresif mengkritik, (b) tindak tutur ekspresif mengeluh, (c) tindak tutur ekpresif menyalahkan, (d) tindak tutur ekspresif memuji, (e) tindak tutur ekspresif mengucapkan terima kasih, (f) tindak tutur 
ekspresif mengucapkan selamat, (g) tindak tutur ekspresif menyanjung.

\section{a. Tindak Tutur Ekspresif Mengkritik}

Tindak tutur ekspresif dengan indikator mengkritik ditandai dengan adanya tuturan dari penutur yang berupa kecaman atau tanggapan yang disertai dengan uraian dan pertimbangan baik atau buruk terhadap suatu karya, pendapat, tindakan dan sebagainya yang ditujukan kepada mitra tuturnya.

Konteks: Kritikan yang ditujukan kepada mitra tutur yang takut terhadap istri, lebih baik menikah lagi saja.

Tuturan: "Wedi Karo Bojo, Kawin Maning Bae".

Tuturan tersebut dalam bahasa Indonesia berarti takut kepada istri, menikah lagi saja. Hal ini dituturkan oleh penutur kepada mitra tutur agar jadi suami jangan takut kepada istri. Jika takut kepada istri, lebih baik menikah lagi karena istri seharusnya patuh terhadap suami bukan sebaliknya. Dengan demikian, tuturan tersebut merupakan tindak tutur ekspresif mengkritik sebab terdapat kritikan yang ditujukan kepada para suami agar tidak takut kepada istri.

\section{b. Tindak Tutur Ekspresif Mengeluh}

Tindak tutur ekspresif dengan indikator mengeluh ditandai dengan tuturan yang berisi keluhan penutur kepada mitra tutur atau pihak yang dituju.

Konteks: Keluhan dari penutur yang terkadang teringat tentang suatu hal pada masa lalu yang dialami oleh penutur.

Tuturan: "Kadang Sok Kelingan Jaman Mbiyen"

Tuturan tersebut dalam bahasa Indonesia berarti terkadang masih teringat zaman dahulu/masa lalu. Dalam hal ini dituturkan bahwa penutur terkadang masih teringat sesuatu yang pernah dialaminya pada masa lalu. Dengan demikian, kutipan tersebut merupakan kutipan dari tindak tutur mengeluh sebab terdapat ekspresi mengeluh dari penutur yang terkadang masih teringat suatu hal yang pernah dialami oleh penutur sendiri. 


\section{c. Tindak Tutur Ekspresif Menyalahkan}

Tindak tutur ekspresif dengan indikator menyalahkan ditandai dengan adanya tuturan dari penutur kepada mitra tutur yang bermaksud menyalahkan perbuatan yang telah dilakukan mitra tutur atau pihak yang bersangkutan dengan penutur.

Konteks: Ungkapan menyalahkan dari penutur kepada perempuan yang salah dalam mengartikan kerudung.

Tuturan: "Kerudung Formalitas"

Tuturan tersebut dituturkan oleh penutur kepada mitra tutur khususnya kepada perempuan tentang pengertian menggunakan sebuah kerudung. Menggunakan kerudung seharusnya bersikap sopan santun dan mengekspresikan diri sesuai ajaran agama Islam. Dengan demikian, tuturan tersebut merupakan tindak tutur menyalahkan sebab terdapat ungkapan penutur yang menyalahkan perempuan yang salah dalam mengenakan kerudung.

\section{d. Tindak Tutur Ekspresif Memuji}

Tindak tutur ekspresif dengan indikator memuji ditandai dengan adanya tuturan dari penutur untuk memuji kepada mitra tutur atau pihak yang dituju.

Konteks: Ungkapan memuji dari penutur untuk istrinya yang sakinah.

Tuturan: "Istri Sakinah"

Tuturan tersebut dituturkan oleh penutur untuk memuji istrinya. Dengan demikian, kutipan tersebut merupakan tindak tutur memuji sebab terdapat ungkapan memuji dari penutur yang ditujukan untuk istrinya yang sakinah.

\section{e. Tindak Tutur Ekspresif}

\section{Mengucapkan Terima Kasih}

Tindak tutur ekspresif dengan indikator mengucapkan terima kasih ditandai dengan tuturan dari penutur terhadap mitra tutur yang berisi sebuah ucapan terima kasih atas hal yang telah dilakukan oleh mitra tutur atau pihak yang dituju. 
Konteks: Tuturan terima kasih yang ditujukan untuk istrinya yang selalu memberi doa

Tuturan: "Doamu Harapanku"

Tuturan tersebut, dituturkan oleh penutur kepada mitra tutur untuk berterima kasih atas doa yang selama ini mengiringi perjalanannya. Dengan demikian, kutipan tersebut merupakan tindak tutur ekspresif mengucapkan terima kasih sebab berisi tuturan yang menyatakan mengucapkan terima kasih yang dituturkan penutur kepada mitra tutur atas doa yang telah dipanjatannya selama ini.

\section{f. Tindak Tutur $\quad$ Ekspresif}

\section{Mengucapkan Selamat}

Tindak tutur ekspresif dengan indikator mengucapkan selamat ditandai dengan adanya tuturan dari penutur untuk mengucapkan selamat kepada mitra tutur atau pihak yang dituju.

Konteks: Ucapan selamat dan sukses yang ditujukan kepada mitra tutur.

Tuturan: "Selamat dan Sukses"
Tuturan tersebut, dituturkan oleh penutur kepada mitra tutur untuk mengucapkan selamat dan sebuah harapan agar sukses dalam hidupnya. Dengan demikian, kutipan tersebut merupakan tindak tutur ekspresif mengucapkan selamat sebab terdapat ungkapan dari penutur yang mengucapkan selamat kepada mitra tutur dan disertai sebuah harapan agar sukses dalam hidupnya.

\section{g. Tindak Tutur Ekspresif Menyanjung}

Tindak tutur ekspresif dengan indikator menyanjung ditandai dengan adanya tuturan dari penutur kepada mitra tutur untuk mengungkapkan sesuatu yang bersifat menyanjung mitra tutur atau pihak yang dituju.

Konteks: Ungkapan sanjungan yang ditujukan kepada pejuang yang dilampirkan dengan gambar sosok Bung Karno.

Tuturan: "Perjuanganku"

Tuturan perjuanganku dituturkan untuk menyanjung perjuangan dari sesosok tokoh Presiden Soekarno yang dinyatakan pada 
gambar di sebelah tulisan pada bak truk. Dengan demikian, tuturan tersebut merupakan tindak tutur ekspresif menyanjung karena terdapat unsur sanjungan yang dituturkan untuk menyanjung perjuangan dari tokoh Presiden Soekarno yang dilampirkan pada gambar di sebelah tulisan bak truk.

\section{Alternatif Materi Ajar Pragmatik}

Setelah mahasiswa mendapatkan informasi tentang hakikat tindak tutur dan jenis tindak tutur, kemudian pengajar menjelaskan materi selanjutnya yaitu tentang tindak tutur ekspresif dan jenis-jenisnya. Penjelasan diberikan dengan menggunakan LCD untuk menayangkan pokok-pokok materi tentang tindak tutur ekspresif kelompok kata yang tertulis pada bak truk. Pada proses pembelajaran ini, dosen memberikan lembaran gambar bak truk yang terdapat tuturan, kemudian hal ini dipergunakan sebagai bahan analisis mahasiswa sesuai tugas yang telah diberikan dosen yaitu mencari unsur-unsur tuturan yang mengandung tindak tutur ekspresif kelompok kata yang tertulis pada bak truk. Dalam menganalisis tuturan yang mengandung tindak tutur ekspresif kelompok kata yang tertulis pada bak truk, metode pembelajaran yang digunakan yaitu metode tanya jawab dan diskusi. Berikut ini contoh materi yang diberikan oleh dosen mengenai tindak tutur ekspresif pada bak truk.
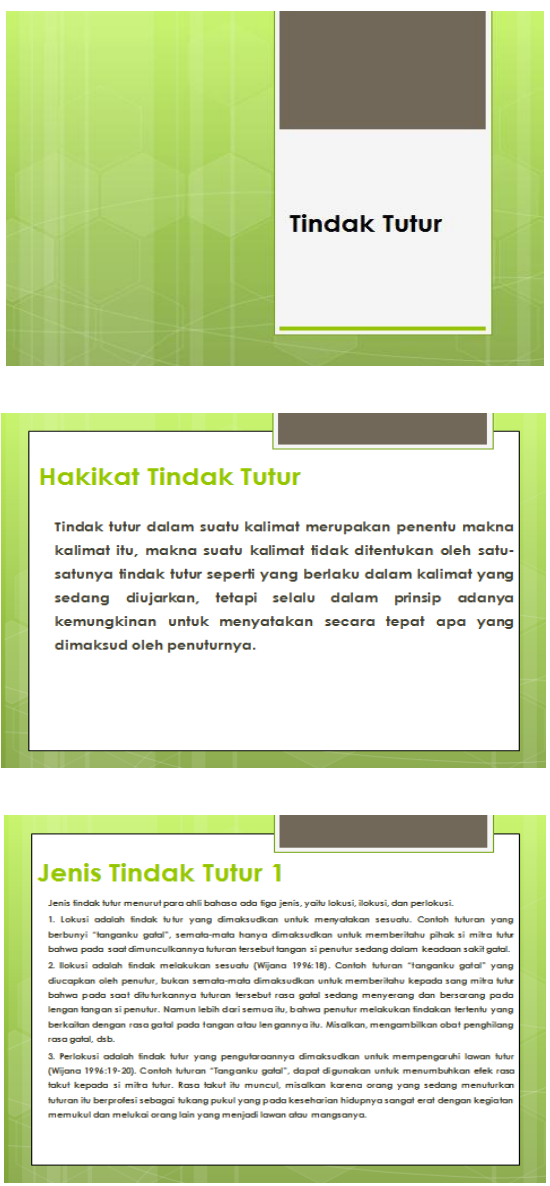

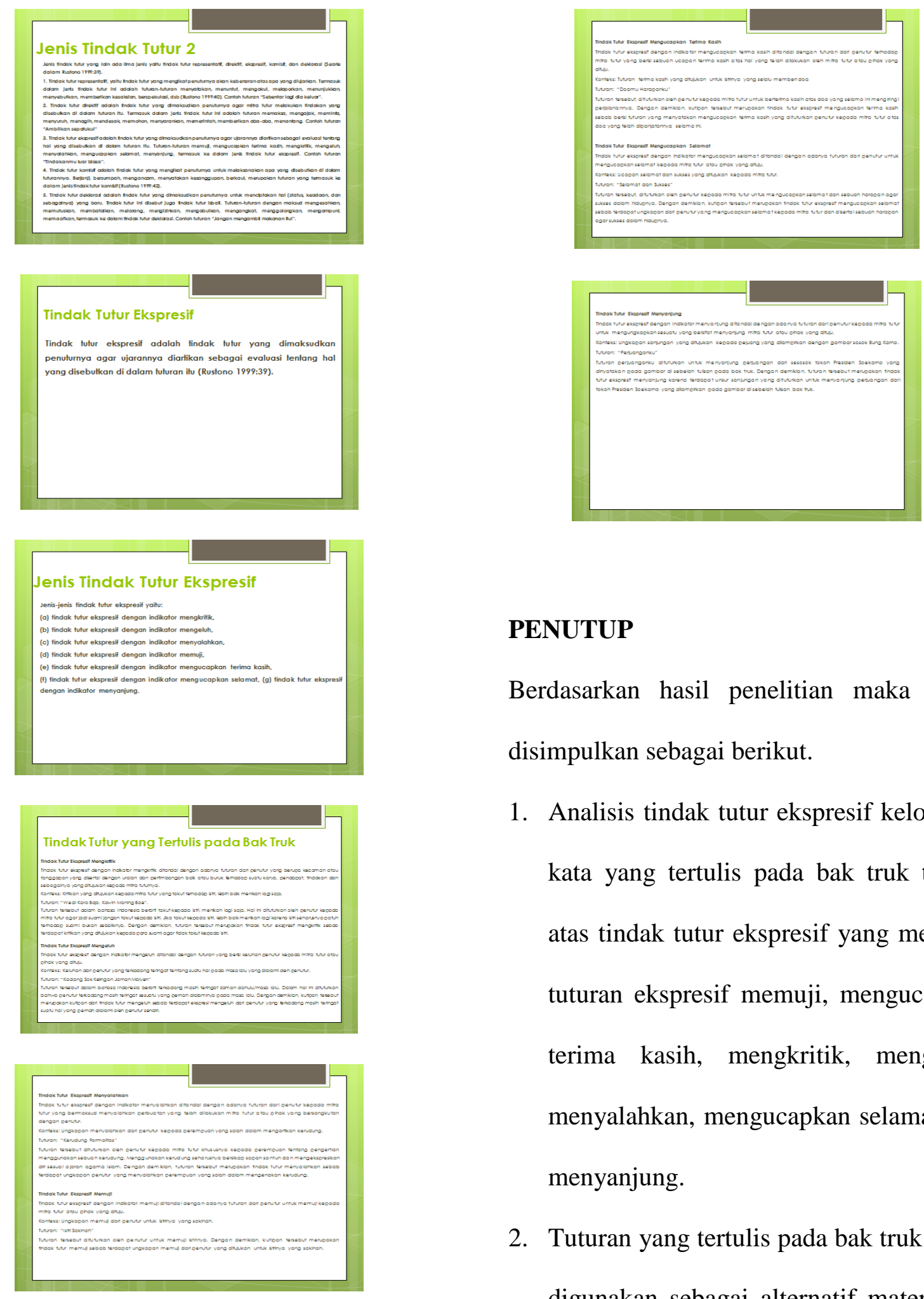

\section{PENUTUP}

Berdasarkan hasil penelitian maka dapat disimpulkan sebagai berikut.

1. Analisis tindak tutur ekspresif kelompok kata yang tertulis pada bak truk terdiri atas tindak tutur ekspresif yang meliputi tuturan ekspresif memuji, mengucapkan terima kasih, mengkritik, mengeluh, menyalahkan, mengucapkan selamat dan menyanjung.

2. Tuturan yang tertulis pada bak truk dapat digunakan sebagai alternatif materi ajar Pragmatik. Materi yang diberikan berupa informasi tentang hakikat tindak tutur, 
jenis tindak tutur, tidak tutur ekspresif, jenis-jenis tindak tutur ekspresif, dan tindak tutur ekspresif yang tertulis pada bak truk.

\section{DAFTAR PUSTAKA}

Depdiknas. 2005. Kamus Besar Bahasa Indonesia. Jakarta: Balai Pustaka.

Moleong, Lexy. J. 1990. Metode Penelitian Kuantitaif. Bandung: Remaja Rosdakarya.

Purwo, Bambang Kaswanti. 1990. Pragmatik dan Pengajaran Bahasa. Jakarta: Balai Pustaka.

Rahardi, Kunjana. 2003. Berkenalan dengan Ilmu Bahasa Pragmatik. Malang: Dioma.

Rustono. 1999. Pokok-Pokok Pragmatik. Semarang: CV IKIP Semarang Press.

Sudaryanto. 1993. Metode dan Aneka Teknik Analisis Bahasa: Pengantar Penelitian. Yogyakarta: Duta Wancana.

Wijana, I Dewa Putu. 1996. Dasar-Dasar Pragmatik. Yogyakarta: Andi Offset.

Yule, George. 1996. Pragmatik. Yogyakarta: Pustaka Pelajar. 